\title{
The National Ocean Conference
}

Kenneth Brink

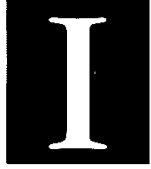

n recognition of Vasco da Gama's great voyage from Portugal to India, 1998 was designated by the United Nations to be the International Year of the Ocean. Globally, the year has been marked by events such as the Lisbon World's Fair. Most prominent among the numerous United States activities has been the National Ocean Conference, held in Monterey, June 11-12. Many academics probably know little about the event or have much concern about what was accomplished there. It was nonetheless an important occurance, and worth a bit of closer consideration.

The National Ocean Conference was meant to be a forum to pull together the academic, governmental, environmental and business sectors that have an interest in the ocean. There were initial parallel half-day sessions to consider issues such as exploration and research, fisheries, and national security. These were followed by a plenary session where the results of these groups were discussed with the Vice President, and by a second day where a number of political figures, including the President himself, gave speeches about the ocean. With hundreds of people in attendance, and time for truly open discussion limited, it is fair to say that no issues could be treated in much depth. Of the four sectors represented at the meeting, the environmental ("green") organizations were clearly the most visible, and the business sector was probably the least visible. As an academic, I had always had the feeling that the main people interested in the ocean were scholars, governmental people (including the Navy) and a scattering of fisheries people. It was a major awakening for me to see how large and strong a voice the environmental community represented.

One could ask what sorts of results were obtained at this meeting. A number of funding initiatives were announced, although it was not very clear to what extent these represented genuinely new undertakings, as opposed to simply announcing projects that would have happened in any case. A showpiece moment was when the President declared further moratoria on offshore oil drilling, but this was not something that was of much scientific substance either (although the local political effect was likely substantial). Instead, what was really important about the meeting was simply the good feelings, and the fact that for at least a while, the attention of our national leaders was genuinely focused on the Ocean. This in itself represents a wonderful start in gaining national attention for the ocean sciences, and each of us, in his or her way, can now help to exploit this momentum to improve the visibility, status and effectiveness of the field.

एव

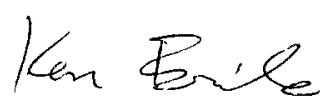

This special issue was made possible by the U.S. Office of Naval Research.

This work relates to Department of Navy grant N00014-98-1-0566 issued by the Office of Naval Research.

The United States Government has a royalty-free license throughout the world in all copyrightable material contained herein.

Abstracts were previously published, unedited, as Oceanography, Vol. 11, No. 2 Supplement. 